it is entirely possible that the natural demand for coal could be more like 100 million tons a year than the 155 million tons now planned for. The traditional customers are melting away. In a few years there will be a demand for 70 million tons or so of coal each year from power stations now working or being built, a demand for 20 million tons or so of coking coal each year for making steel, and the rump of that traditional but anachronistic market for coal to be burnt on open hearths in people's houses. But who else will want to burn coal ? And who else will be able to afford to do so ? In all the circumstances, it might have been safer and in the long run kinder to the men concerned if the Government had sought to anticipate the changes which are now well under way and not to delay them. It would have made more sense to aim at a contraction from the present rate of production of 164 million tons a year to something more like 140 million tons a year or even less by the end of the decade, and then to have done whatever may be necessary to see that people and communities robbed of work are given other things to do.

\section{UNLUCKY S'TRIKE}

Columbia UnIversity seems to have made a serious error of judgment in its decision to undertake the management of a new cigarette filter. Even if the filter turns out to be as effective in removing tar and other condensates from cigarette smoke as its inventor, Dr Robert Strickman, claims, the university will have some tedious explanation to provide. It is therefore important to be quite clear that nobody objects-or should object-to the university making money. The independent universities in the United States are respected as well as envied by similar institutions elsewhere. The way in which they are able to live by their own laws must naturally seem a great opportunity to others less favourably placed. The fact that they have chosen to devote so much of their resources to creative scholarship is a striking proof of their highmindedness. In the last resort, their freedom is based on their financial independence. Yet there are some ways in which universities, however great, cannot live by the simple rules which govern commercial enterprises. There are some kinds of money which they should not make, and there are some ways of making money which they should avoid. Some of this seems to have been forgotten in all the ballyhoo attending the launching of the new filter on July 13.

In the first place, it is entirely mystifying that the university should have taken such trouble to make a great occasion out of its public announcement that Dr Strickman had been generous enough to transfer to the university most (though not all) of his rights in the new filter. Columbia knows enough about the ways in which newspapers work to know that it is almost impossible to hint that an important announcement on smoking and health is on the way without whipping up excitement. In the event, trading in tobacco shares on the New York Stock Exchange was stopped between midday and the point later in the afternoon at which stockbrokers could inform themselves about the news which Columbia had to broadcast.

And that, of course, was a bitter disappointment. As yet, there is only the most sketchy information about what the filter may accomplish. At Columbia on July 13, both the President, Dr Houston Kirk, and Dr Strickman steadfastly declined to say what the new filter is made of, or how its supposed effectiveness has been demonstrated. With so little to say, it is unlikely that an ordinary commercial company would have been able to create quite such a sensation. Indeed, announcements of improved filters are frequently to be heard. When the New York Stock Exchange stopped trading in tobacco, that was as much a measure of respect for the university as a proof of the statement that the new filter "is 70 per cent more effective" in removing tar from tobacco than other filters now on the market. And in any case, of course, whatever tests there may have been in Dr Strickman's laboratory, it is exceedingly improbable that anybody has had time to carry out clinical tests of the extent, if any, to which the new filter can diminish the incidence of lung cancer.

But should a great university rely on income from tobacco smoking? This is one of the questions now to be asked. Perhaps the first, though the most trivial, thing to say is that the Chancellor of the Exchequer in Britain would immediately be lost if he were deprived of the revenues from tobacco taxes. There will also be echoes of the way in which the Church of England was frequently criticized, before and after the war, for collecting ground rents on houses in London which were known to be used as brothels. The truth is that in a competitive economy it is exceedingly difficult to demand that respected institutions should exercise restraint about investment which others are entitled to ignore, and for practical purposes, of course, few people would object if Columbia were now seeking to make a fortune out of speculation in tobacco stocks. It has exposed itself to criticism only because it has set up what could easily become an intolerable conflict of interest. People will now be tempted to suppose that Columbia in its wisdom has decided that the probable connexion between smoking and lung cancer is illusory. At the press conference last week, Dr Kirk seems to have acknowledged, ineffectually perhaps, that his announcement was not to be taken as a pronouncement that smoking, after all, is safe. He and his colleagues will have to go much further than this if they are to remove the false impression which will have been created by the link between Columbia and the filter-and if they are to conform with the tough new spirit of the regulations of the Federal Trade Commission on tobacco advertising. The trouble, of course, is that if Columbia now embarks, as it should, on a campaign to inform tobacco smokers that there is no evidence that filters bring immunity from lung cancer, it will be undermining the chances of commercial success for its new enterprise. 